\title{
Selected problems of failures and repairs of historic masonry vaults
}

\author{
Rafat Nowak $^{1, *}$ and Romuald Orłowicz ${ }^{1}$ \\ ${ }^{1}$ West Pomeranian University of Technology, Faculty of Civil Engineering and Architecture, \\ al. Piastów 50, Szczecin, Poland
}

\begin{abstract}
The paper discusses the technical condition (state) of existing vaults. Several examples of critical conditions of vaults are presented. Analysis and proper modelling of vaults is discussed. Repair methods were proposed with respect to historical heritage preservation. The maintenance methods of vaults were discussed with pointing the crucial elements. It was noticed that in situ tests are necessary for proper model calibration and repair results verification.
\end{abstract}

\section{Introduction}

In many historical buildings, brick vaults are the basic structures of the ceilings and coverings. Due to their decorative value, they are one of the most important achievements of Gothic architecture. The half cylindrical barrel vaults used in Romanesque architecture have been replaced by a lighter cross vault. The cross vault consists of two barrel vaults, which intersect at an angle and are fitted on a square or rectangular plan. The vaulting is supported in corners by walls or columns. Development of this basic vault, allowed for many other variations, e.g. star, crystal and other vaults $[1,2]$. After many years of exploitation, these vaults often raise concerns about their load-bearing capacity and further safe use. This applies especially to vaults in renovated historic buildings or those undergoing modernization due to a change in the way they are used. Emergency condition of the vault may occur as a result of:

- Degradation of the masonry, including washing out the mortar from joints due to insufficient protection from atmospheric exposure during their long-term non-use (Fig. 1 a).

- Overloads, especially concentrated and moving loads or loads causing vibrations(Fig. 1 b).

- Horizontal and vertical displacements of supports (Fig. $1 \mathrm{c}, \mathrm{d}$ ).

- Removal of the haunch backfill, which should have about $2 / 3$ of its height [3].

- Making holes in order to locate the system (Fig. 3).

- Point supports (instead of centering) as a protection during repair work.

- Switching from compressed system to tensile by suspending it, e.g. to the roof truss [1].

- Unexpected effect, e.g. seismic or paraseismic, fire, etc.

*Corresponding author: rnowak@zut.edu.pl 
- Reinforced concrete jacket on the dorsal side. This causes desalination on the palate of the vault and leads to the lack of vapour permeability, resulting in destruction of the wall [2].

- Repair of the vault without monitoring its damage.

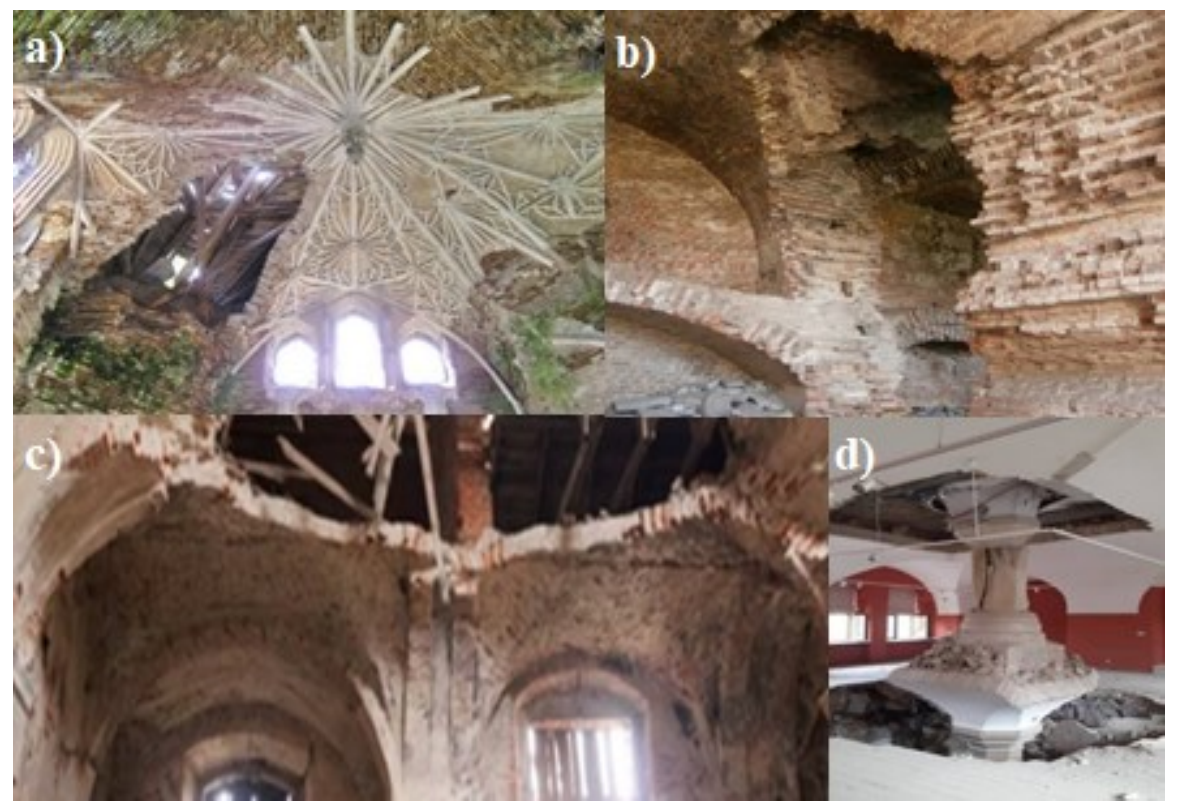

Fig. 1. Examples of vault failures.

The fact that many vaults were not built fulfilling the rules of statics may also be the cause of the failure. It is worth mentioning that the number of studies related to the analysis of behaviour and ways of repairing historic vaults is relatively small, and their research is not very popular [3].

\section{Analysis}

The most sensitive for damage zones of vaults are the headrests, i.e. the plane of vault support. In these planes, apart from compression in the direction perpendicular to the supporting joints of the wall, there are shear stresses caused by the expansion forces [4]. After many years of operation, the vault backrest zones may be damaged due to their overloading. As a result the destruction of masonry may propagate due to freezing under the influence of excessive moistening with rainwater, which due to leaks in the roof slope accumulates in the corner axes of the vault (Fig. 2 a, b). There are also cases of weakening of the support zones with improperly made holes next to them for the location of installation cables (Fig. 2 c). 


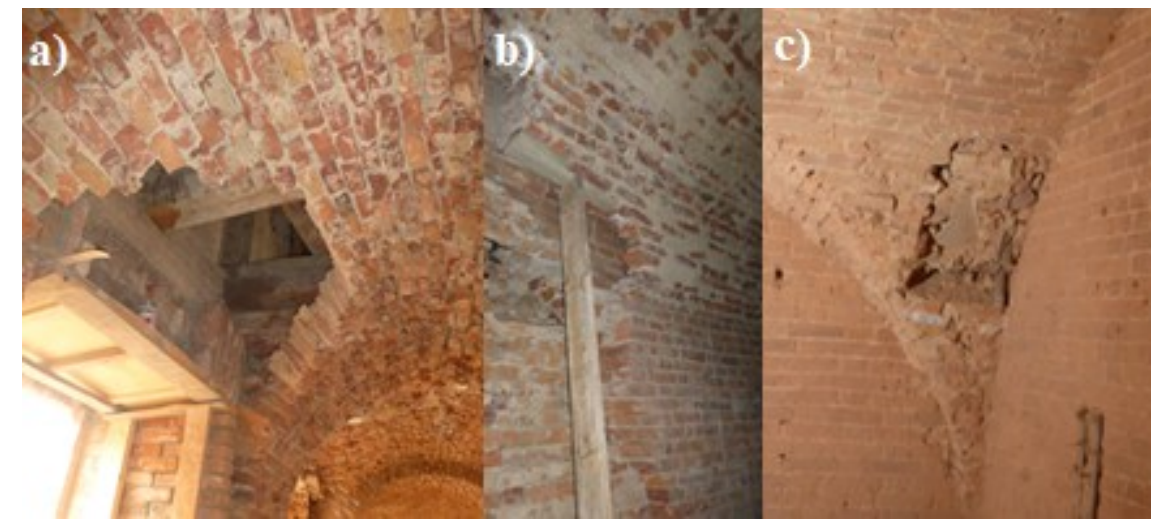

Fig. 2. The damages to support zones in cylindrical $(a, b)$ and cross vault (c).

The adaptation of historic buildings to current standards requires the application of new installation systems, such as ventilation ducts, water or heat supply. In this case it is sometimes necessary to make openings in brick vaults loaded with own weight and payload (Fig. 3 a). The size of the openings may contribute to a significant weakening of the vault and even to the loss of its load-bearing capacity. Figure $3 \mathrm{~b}$ shows a stress distribution map in the area of a rectangular hole, which shows that the compressive stresses increase significantly near the longer sides of the hole. On the opposite side of the hole the stream of compressive forces changes its direction in relation to the longer sides of the hole. This creates tensile stresses parallel to the shorter side of the hole. These stresses may exceed the tensile strength of the masonry perpendicularly to the supporting joints in it and cause the vault to break in this direction [5].

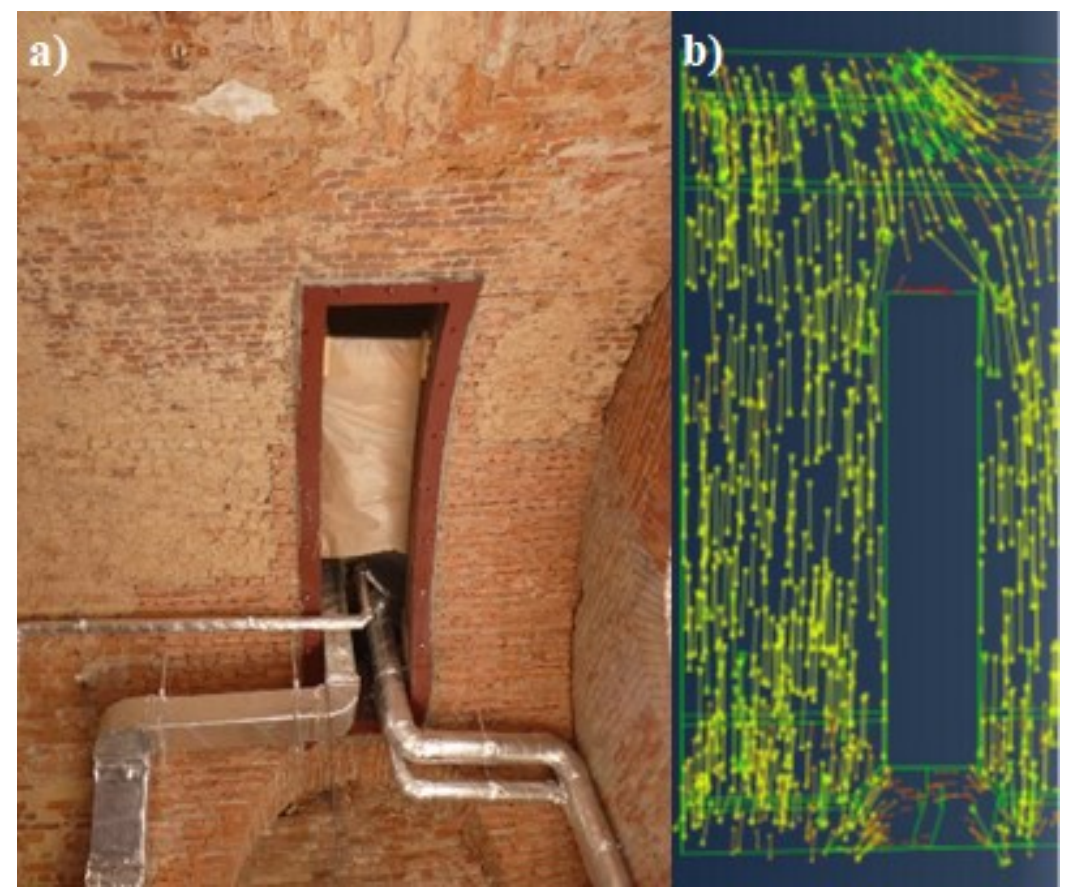

Fig. 3. Process hole in barrel vault (a) stress distribution map around the hole (b). 
The difficulty of static analysis of vaults results from a wide range of structural solutions characterized by shape, level projection, elevation, type of support, etc. The prerequisite for the proper operation of the vaults is to shape their geometry in accordance with the course of pressure lines that depend on the type of existing loads, and transferring the forces down by the shortest route to the ground or supports. The position of the pressure lines in barrel vaults and in flat arched constructions plays a crucial role due to the possibility of damage or complete collapse of the vaults. The most appropriate shaping of vaults is such that the pressure line is located in the core of the cross-section, which means that the entire crosssection of the vault is compressed [3]. Failing to respect the principle in barrel vaults leads to tensile stresses perpendicular to the supporting joints, i.e. in the direction of the least tensile strength of the masonry. As a result, cracks are formed that deeply propagate which may lead to the formation of hinges and as a consequence to the loss of structural stability $[1,3]$.

In cross-shaped vaults, star-shaped vaults, etc., the destruction mechanism has a more complicated character (Fig. 4) [6]. This is due to the distribution of internal forces, as individual fragments of the vaults can work in a complex state of stress (Fig. 5). It is worth mentioning that cracks in these types of vaults, although reveal exceeding of the ultimate limit state of the individual elements, do not always lead to an emergency state of the structure as a whole. Such situation requires an in-depth static and strength analysis based on data on the actual morphology of cracks and their propagation in the vault. Modeling of this type of vaults as membrane shells may be burdened with a significant bias because the actual stress distribution along the vault thickness is not taken into account [1]. It seems that more reliable are models that account for the spatial state of stresses (Fig. 5) caused by longitudinal forces $N$, tangential forces $T$ and bending moments $M$. It is worth mentioning that a similar stress state is easily determined with use of existing numerical methods. Advanced analyses use the MES method to create spatial models, that consider the cooperation of all of the vault components. Available elements (one, two and three-dimensional as well as contact elements) allow to describe sometimes very complicated behaviours and cooperation within the whole vault structure [3]. On the other hand, the basic problem is to estimate the loadbearing capacity of vaults, including the mechanism of their destruction, taking into account the propagation of the cracks [4].

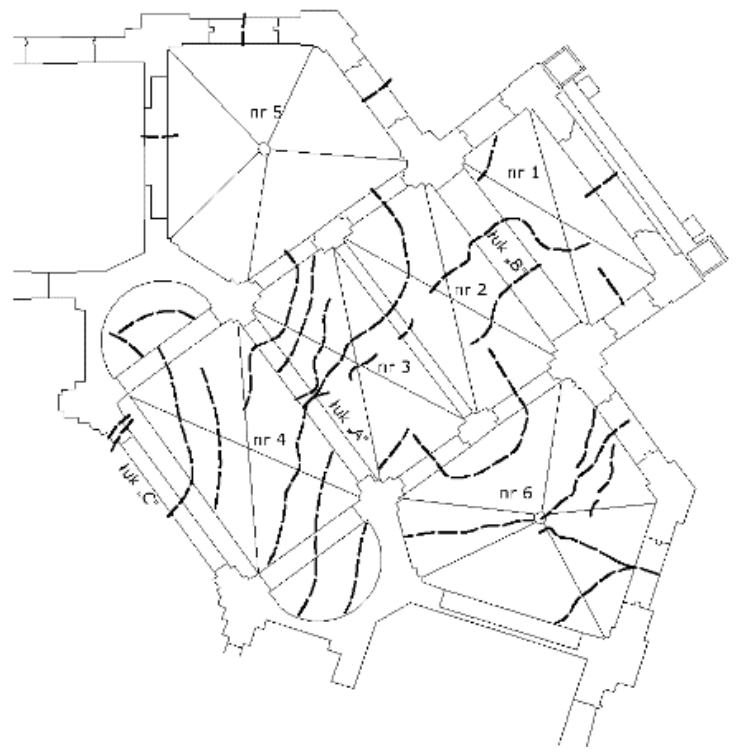

Fig. 4. Cracking of cross vaults. 


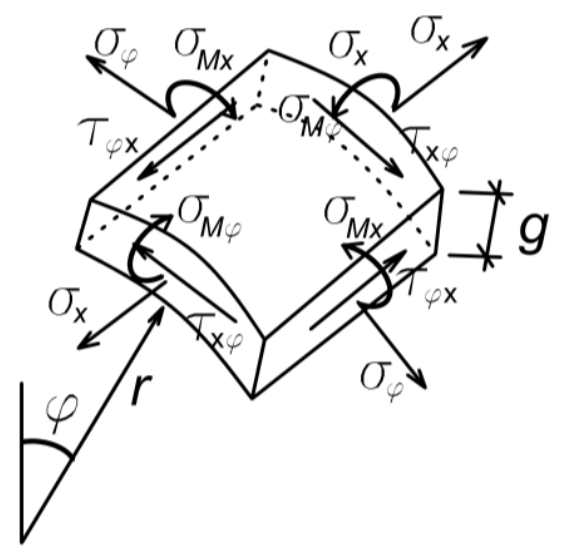

Fig. 5. Internal force distribution in a single element.

\section{Repair and strengthening methods}

The problem is complicated by the fact that for the aforementioned stress state (Fig. 5) there are no proper strength criteria that include the anisotropic properties of the masonry. These criteria are based not only on the calculated static values of stresses, but also on the appropriate values of masonry strength. Some of these values contained in current standards, for example, the compressive, tensile or shear strength of the masonry, cannot be used directly to estimate the bearing capacity of historical vaults. This requires separate material testing in situ or on samples taken from the vaults. With numerical modelling of the brickwork behaviour, taking into account the formation of cracks and their development until the complete destruction (failure) of the vault, experimental correlation describing the cracking energy are required [7, 8]. In order to determine these correlations for historical walls, specialized experimental studies are needed, which are very cumbersome and so far have not been normalized.

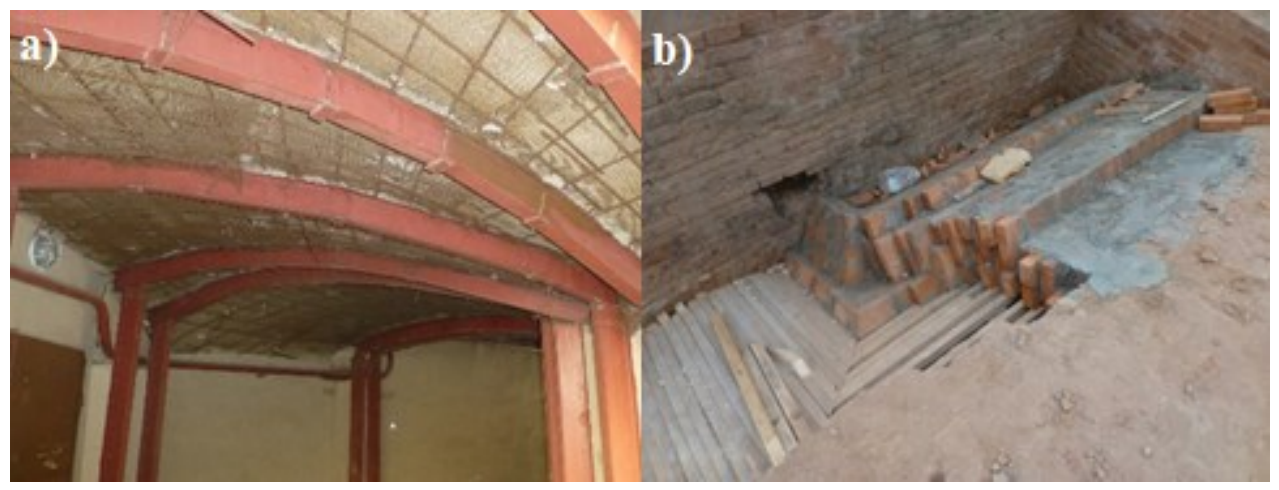

Fig. 6. Reinforcement of the vault using steel centerings (a) and by rebuilding (b).

The lack of certainty as to the actual load-bearing capacity of damaged vaults makes it difficult to protect them against failures and to choose the proper repair methods. Not all known methods of wall repairs, which are suitable for a flat state of stress [8], can be applied to repairing vaults. Moreover, methods and technologies of repairing historic vaults often require the approval of conservation authorities [2]. An example of this can be repair solution 
quoted in Fig. 6 a, which not only exposes the user to unjustified costs, but also results in the loss of the historical value of the object.

The accepted and frequently used methods of repairing historical vaults include $[1-3,6,8,9]$ :

- Injection of the cracks,

- Reinforcing with lamellas (Fig. 7 a) or composite meshes (Fig. 7 b),

- The use of ties to prevent horizontal movement of the vault supports,

- Use of stiffening ribs (usually on the dorsal surface of the vault) made of reinforced concrete, masonry, steel sections and even glued laminated wood.

In special cases it may be necessary to rebuild masonry the most damaged parts of the vault (Fig. 6 b). However, this method requires abiding of a certain production technology regime, consisting not only in the proper selection of wall components (bricks and mortar) but also their proper cooperation with the remaining wall of the vault.

The supplementary materials must be chosen carefully, as the use of a material with different elastic characteristics can seriously disrupt the internal forces in the vault. Purchased material should be tested to determine their declared characteristics. Unfortunately, due to imperfections in the production processes the characteristics of products can be elevated above the declared level.

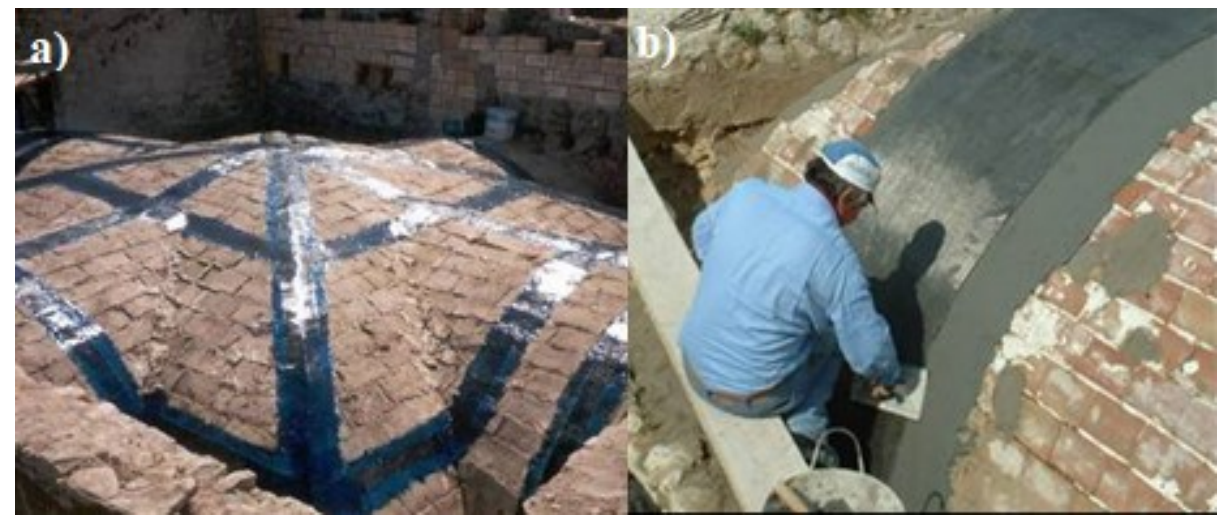

Fig. 7. Repair of the vault using FRP strips (a) and mats (b).

One method of strengthening damaged vaults is the use of steel tie rods, which stop the horizontal movement of the supports. However, this solution interferes with the appearance of the vault, which requires the consent of the monument conservator.

Reinforcing the vault with ribs (Fig. 8,9) from the upper side can be a good idea, but requires temporary removal of the backfilling. This type of reinforcement can be found in some of the existing vaults in the form of brick ribs (Fig. 9 b). The reinforcement can be also constructed as reinforced concrete (Fig. 9 a) arches parallel to the surface of the vault (at its junction). Alternatively, steel sections (Fig. 9 d) or glued laminated timber (Fig. 9 c) can be used. The connection between the ribs and the vault is however problematic, but can be usually done with steel anchors or clamps. These connections should be regarded as susceptible in the calculations. In addition, when the vault is directly loaded, they should be modelled as suspended to the ribs. This can result in tensile stress relief. It is therefore advisable to load the vault by means of additional members that directly transmit the loads to the ribs with exclusion of the vault itself. 


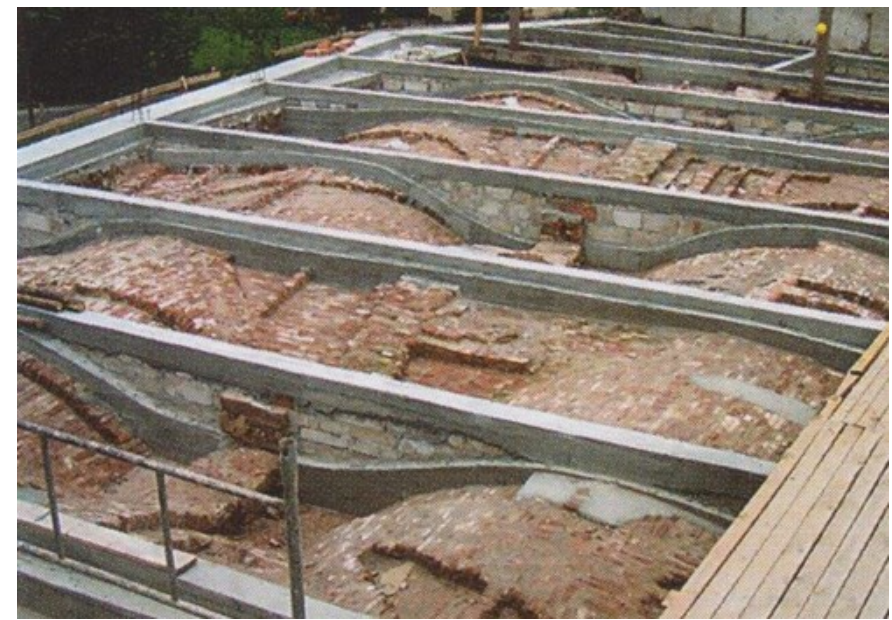

Fig. 8. Example of vault strengthening with reinforced concrete ribs [1].

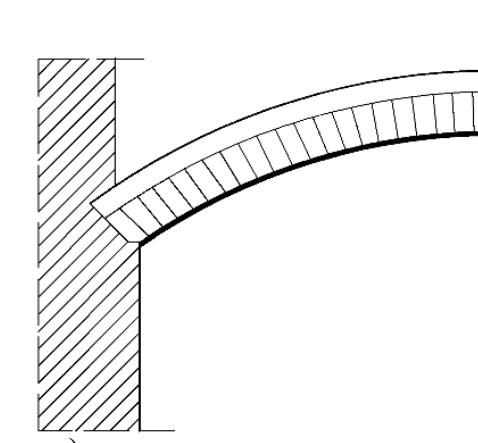

a)
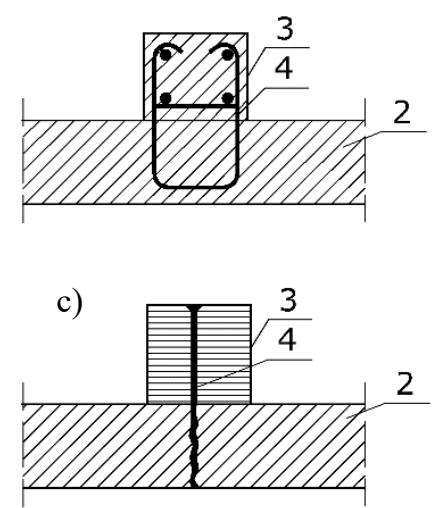

A - A

b)
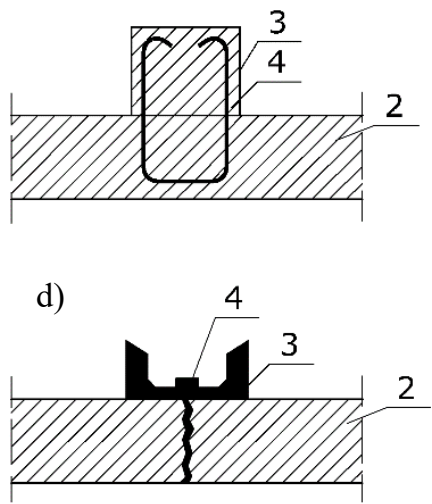

Fig. 9. Methods of vault strengthening with ribs : a) reinforced concrete, b) brick, c) glued laminated timber, d) steel sections ( 1 - walls, 2 - masonry vault, 3 - reinforcing ribs, 4 - steel anchors).

It is also often necessary to consider relieving the vault by replacing the backfill with lighter material [10], such as e.g. expanded clay. It should be remembered that it is not allowed to completely remove the backfill as it plays a crucial role in the total load-bearing capacity and statics of the vaults.

Before putting the vault into service after repairs are done, it is recommended to carry out loading tests appropriately measuring the influence of applied reinforcement. It can be performed using strain gauges or inductive sensors, which will allow to verify the changes in 
the structure's work. Obtaining a detailed calculation model for the plastic range of the actual vault is very time-consuming and costly, as it requires many specialist laboratory tests to calibrate all parameters of the model. Often it will only be possible to analyze the elastic range, which is burdened with certain imperfections. Therefore, it may be extremely important to carry out experimental verification after the introduction of repairs.

\section{References}

1. J. Jasieńko, T. Łodygowski, P. Rapp, Naprawa, konserwacja i wzmacnianie wybranych, zabytkowych konstrukcji ceglanych (Dolnośląskie Wydawnictwo Edukacyjne, Wrocław, 2006) [in Polish]

2. I. Tejchman, Standardy $w$ zakresie projektowania, realizacji $i$ nadzorów prac konserwatorskich dotyczacych zabytków architektury $i$ budownictwa (Narodowy Instytut Dziedzictwa, Torun - Warszawa, 2014) [in Polish]

3. Z. Janowski, Ł. Hojdys, P. Krajewski, Sklepienia zabytkowe - klasyfikacja, ocena stanu technicznego i nośności, naprawy i wzmocnienia, (Proceedings of XXII Conference „Warsztaty pracy projektanta konstrukcji”, Szczyrk, 2007) [in Polish]

4. R. Nowak, R. Orłowicz, Przegląd Budowlany, 11, pp. 38-40 (2018) [in Polish]

5. R. Orłowicz, R. Nowak, Przegląd Budowlany, 12, pp. 30-31 (2017) [in Polish]

6. A. Rzeszotarski, R. Orłowicz, R. Nowak, Wiadomości Konserwatorskiego, 26 (2009) [in Polish]

7. S. Jemioło, L. Małyszko, MES i modelowanie konstruowanie $w$ analizie zniszczenia konstrukcji murowych, T.1, (Wydawnictwo UWM w Olsztynie, 2013) [in Polish]

8. L. Małyszko, R. Orłowicz, Konstrukcje murowe. Zarysowania i naprawy (UWM, Olsztyn, 2010) [in Polish]

9. R. Orłowicz, R. Nowak, Inżynier Budownictwa, 1, pp. 115-117 (2017) [in Polish]

10. P. Krajewski, Analiza wpływu materiału zasypowego na nośność sklepień murowych. (Doctoral dissertation, Kraków, 2010) [in Polish] 